Journal of Southeast Asian Human Rights, Vol. 1 No. 1 June 2017. pp. 1-15

(C) University of Jember \& Indonesian Consortium for Human Rights Lecturers

\title{
Can Human Rights and Indigenous Spirituality Prevail over State-Corporatism? A Narrative of Ecological and Cultural Rights Violation from East Kalimantan, Indonesia: An Activist Perspective
}

Mirza Satria Buana

Faculty of Law, University of Lambung Mangkurat, Indonesia

\begin{abstract}
This article examines theoretical and empirical discussions of strategies to overcome statecorporatist and developmentalist practices in East Kalimantan, Indonesia. The term statecorporatism describes a political condition in which the state maintains strong links to state backed groups. Developmentalism is an overarching concept used to describe the tendency of a state to maximize economic growth through investment while disregarding the fundamental rights of its people. The case of East Kalimantan Province was selected due to its status as one of the most resource-rich provinces of Indonesia. However, the province's wealth of natural resources has also led to widespread deforestation and to the displacement of its indigenous peoples. This paper seeks to analyse the ways in which indigenous spirituality and activism can lessen the negative effects of 'development' projects sustained by state-corporatism. This article contemplates what strategies that can be executed to diminish state-corporatism effects in East Kalimantan, particularly in two important districts: Regency of Kutai Kartanegara and Bontang Municipality. This article argues that the indigenous spirituality is a key to battle state-corporatism's influences. Indigenous spirituality as forum internum is still a potential tool of advocacy. By capitalizing the role of shamans, indigenous peoples might still have opportunities to reclaim and defend their cultural rights.
\end{abstract}

Keywords: Indigenous Rights, Indigenous Spirituality and State-Corporatism

\section{BACKGROUND}

This article examines both theoretical and empirical discussion of strategies to overcome state-corporatist and developmentalist practices in East Kalimantan, Indonesia. Statecorporatism is a term used to describe a political condition in which a state maintains strong links with state backed groups (in this case, extractive companies), both of which use each other as instruments rather than negotiating partners. ${ }^{1}$ Developmentalism is an overarching

1 L Weiss, The Limit of Powerless State, (Cornell: Cornell University Press, 1998), 8. 
concept that describes the tendency of a state to maximize economic growths through investment while disregarding its own citizens' fundamental rights. ${ }^{2}$

The case of East Kalimantan Province was selected due to its enournous amount of natural resources compared to other provinces in Indonesia. The province has abundant reserves of coal, timber and crude oil. ${ }^{3}$ However, the wealth of resources found within this province has been severely depleted recently, to the detriment of its people. ${ }^{4}$ Since the beginning of the centralized Suharto regime to the current era of decentralization in Indonesia, both the national and local governments have allowed several multi-national and national companies to extract East Kalimantan's natural resources through their practices of state-corporatism and clientelism. ${ }^{5}$

Those 'development' practices have also disregarded the fundamental rights of East Kalimantan's local and indigenous peoples. Almost $60 \%$ of East Kalimantan's land area is in critical condition ecologically. In 2015, areas in critical condition have expanded to 7,759,366 hectares. 5,413,251.47 hectares are forest for industrial areas, and while 2,362,176.62 hectares are outside of forest for industrial areas. ${ }^{6}$ The data shows that forest for industrial estate areas that are ecologically and economically vital for local and indigenous peoples are the areas most vulnerable to human rights violations.

This paper seeks to analyse in what way the principles of human rights and indigenous spirituality can lessen the negative effects of "development" projects sustained by statecorporatist practices. This article considers the strategies that can be implemented to diminish the role of state-corporatism in East Kalimantan, particularly in two important districts: the regency of Kutai Kartanegara and the municipality of Bontang.

In the following sections, this article will provide some background on the political and economic situations in East Kalimantan, and present several conceptual frameworks through which to analyse the province's prospects. Information on indigenous spirituality, obtained through fieldwork consisting of interviews and observation, will be used to strengthen arguments for human rights defense in Indonesia. Ultimately, this article concludes that indigenous spirituality and conscience is a key factor in encouraging resistance to state-corporatist and developmentalist intrusion.

2 M.S Buana, State Courts, Traditional Dispute Resolution and Indigenous Peoples in South Kalimantan: A Socio-Legal Study (PhD Thesis, University of Queensland, 2017), 23.

3 Y Vidyattama, Hares and Tortoises: Indonesia's Regional Development Kaleidoscope (Presentation to the ANU Indonesia Update, September 20, 2013) 22.

4 Indonesia's Coal Mining Sector: A Silver Lining behind Dark Clouds, Global Business Guide Indonesia <http://www.gbgindonesia.com/en/energy/article/2016/indonesia_s_coal_mining_sector_a_silver_linin g_behind_dark_clouds_11613.php>.

5 M Faisal, State Structural and Institutional Transformation and the New Dynamics of Business Power, Corruption and Clientelism in Indonesia, (PhD Thesis, University of Queensland, 2013$), 5$.

6 Interview with Pradarma Rupang (Lung Anai Village, 28 May 2017). See also, <http://www.mongabay.co.id/2017/03/27/masyarakat-kalimantan-timur-menderita-akibat-lingkunganyangrusak/\#>. 


\section{II.STATE CORPORATISM AND DEGENTRALIZATION IN EAST KALIMANTAN}

Theoretically speaking, it is impossible to alienate entirely state actors from companies, because both are interdependent upon one another. ${ }^{7}$ Companies need their governments to issue legal concession permits so their concession projects can be established, while the state needs companies to invest in their communities. However, companies have the stronger bargaining power. Indonesia in general is a highly market-oriented environment in which political elites need businesses to thrive, particularly in this era of decentralization in which regions compete to demonstrate high rates of economic growth. Corporations will not establish their projects in a country if there is no legal certainty there. The economic and political environments must be favourable for business. ${ }^{8}$ If companies cancel their project in one state, there will be two main consequences: fewer goods will be produced and employment will plummet.

Fuchs and Lederer state that the power relationship between the state and corporations is adversarial and zero-sum: businesses will gain power when the role of state declines, and vice versa. ${ }^{9}$ This article rejects that thesis by arguing that the power relationship between the two is pragmatic and dynamic, because in order to sustain their power, both business actors and state actors can informally switch their roles.

Recent gubernatorial and legislative elections in some Indonesian regions rich in natural resources have demonstrated that candidates for governor were either supported by private sector actors (mostly extractive industries) or their own companies. This unholy alliance is manifest, as economic and political interests merge pragmatically. In this case, it is not the people who are sovereign (through democratic elections), but the tight relationship between the public and private sectors. This is a win-win solution for them, and a lose-lose solution for marginalised people. When political actors can freely mobilize their business interests in the public policy arena, state-corporatism becomes an immensely effective strategy of governance.

To make things even worse, state-corporatism and its collusive and corruptive characteristics have expanded due to the 'big-bang' decentralisation policies undertaken in the Reformation era. ${ }^{10}$ Some researchers have claimed that decentralisation has several advantages for a post-authoritarian country like Indonesia. Their claims are based on following arguments:

1. It stimulates accountability within the system of government because communities actively participate in local politics through direct local elections; ${ }^{11}$

2. It is more responsive to local needs, because local authorities live nearby and experience the ways of living of local people, thus they are aware of people's needs; ${ }^{12}$

\footnotetext{
7 Faisal, supra, note 5, 15.

8 Ibid 16.

9 Funchs, Doris, Lederer and Markus ML, et al, "The Power of Business" (2007) 9(3) Business and Politics.

10 Vidyattama, supra note 3, 5.

11 Richard Crook and James Manor, Democracy and Decentralization in South Asia and West Asia (Cambridge: Cambridge University Press, 1998) 6.

12 J.Ribot, Waiting for Democracy: The Politics of Choice in Natural Resource Decentralization (World Resource Institute, 2004), 11.
} 
3. It could worsen disparity among communities economically. ${ }^{13}$

However, there are also counter-arguments for decentralisation. The degree of local government accountability does not always correlate with public participation. Structurally, decentralization establishes several government organs that often work ineffectively, and it may contribute to weak coordination among them. ${ }^{14}$ This article argues that the supposed responsiveness and accountability of decentralisation cannot be satisfactorally demonstrated by theories, because they are empirical questions.

In the case of East Kalimantan, which can also be generalised to other regions rich in natural resources, decentralisation has hastened environmental destruction, because local leaders have greater authority to issue mining and logging permits. Driven by economicinvestment motives, East Kalimantan Province has been divided into several regencies. Kutai Regency was divided into four regencies: East Kutai, West Kutai, Bontang City and Kutai Kartanegara. These newly established regencies have independent authority, local government apparatus and regional heads. These expansive local privileges have widened the scope of state corporatism.

The result is predictable. The regency of Kutai Kartangara alone has issued 486 coal mining concession permits, the biggest number in East Kalimantan. ${ }^{15}$ There are several big business actors for coal mining industry. The largest corporation has divided up its concession permit to several sub-contractual companies operating throughout East Kalimantan. Decentralization has made the permit procedure politically transactional.

Due to extractive practices by these sub-contractual companies, several villages have been contaminated by hazardous waste. In the villages of Kabo Jaya and Bukit Pelangi, villagers have reported that the Sangatta River, the only source of clean water, has been contaminated by chemical waste. ${ }^{16}$ Recently, giant crocodiles devoured two villagers, an accident which has never occured before. The local shaman stated that it happened because the cosmological equilibrium between nature and humanity has been disturbed. ${ }^{17}$

Some villages have disappeared entirely due to the spread of coal mining concessions, such as Mulawarman and Kertabuana villages in the regency of Kutai Kartanegara. Kertabuana village was once known as the biggest Rice Processing Unite (RPU) in East Kalimantan. However, the industry has largely collapsed due to lack of land for rice paddies. ${ }^{18}$

Coal mining concessions have spread from East Kutai Regency, passed through Bontang City, and arrived on the edge of Loa Kulu village in Kutai Kertanegara Regency. During the rise of decentralization policies in 1999, six new sub-contractual companies have emerged in Kutai Kertanegara Regency alone. ${ }^{19}$

\footnotetext{
13 H Wolman, Decentralization: what it is and why we should care in Bennett RJ (ed), Decentralization, Local Government, and Market: Toward A Post-War Welfare Agenda (Oxford: Clarendon, 1990).

14 M.S Buana, Understanding Indigenous Cultural Rights in Indonesia through the logic of Village Law: A Nexus between Governance Networks and Legal Pluralism (Forthcoming in September 2017).

15 Interview with Kahar Al- Bahri, (Samarinda, 20 May 2017). See also,

<http://www.kliktenggarong.com/berita-2079-1404-izin-tambang-tumbuh-di-kukar.html>.

16 Interview with Abah Masdar, (Nyerakat village, 23 May 2017).

17 Interview with Abah Masdar (Nyerakat village, 22 May 2017).

18 Interview with Ketut (Nyerakat village, 22 May 2017).

19 Interview with Naem (Kutai Kertanegara, 26 May 2017).
} 
Taking a stroll along Kutai Kertanegara's riverbank is enjoyable but at the same time also ironic. Ships and coal barges pass through constantly, bringing their product downstream. East Kalimantan is the biggest producer of coal in Indonesia; however, its peoples continue to live desperate lives. The new state-corporatist regimes continuously violated the rights of their citizens. ${ }^{20}$ In Benua Puhun village, residents must accept the air pollution caused by coal dust in their living spaces. ${ }^{21}$ Some schools in Bakungan village have had to be relocated because of the high level of air pollution there. ${ }^{22}$ These empirical conditions have prompted a critical question of what human rights can offer to lessen the negative effects of state-corporatism in East Kalimantan, as well as how the relationship between development and human rights should be portrayed.

\section{DEVELOPMENT AND HUMAN RIGHTS: A CONGEPTUAL DEBATE}

This section frames the discussion into two separate arguments. The first argument comes from a developmentalist perspective and considers economic growth as the first reference for law and public policies. The second argument is a human rights view on development as a right.

\section{Economic Growth as a Guiding Star}

Historically, development and human rights have been depicted as inherentally contradictory. Developmentalists often promote this zero-sum argument to justify the presence of extractive industries in developing countries. ${ }^{23}$ Mendelson, one of the most outspoken developmentalists, argues that state law must follow economic development. Economics is the guiding star of state, and state law is merely a subordinate of economic development. ${ }^{24}$ His argument can be traced from evolutionist's point of view: the evolution of the state, from its primitive form to modern day, is driven entirely by humanity's instinct to collect power and wealth. Societal evolution is based on economic pragmatism alone. ${ }^{25}$

Mendelson elaborates that a country's development must undergo three stages. First, the country undergoes a process of unification, which helps the state to consolidate and expand its power to its citizens and colonies. Secondly, the country achieves internal stability, allowing it to focus on its economic growth through massive industrialisation. Finally, after surviving the detrimental effects of industrializaiton, the state achives an

20 Mike Ives, Indonesia Coal Mining Boom is Leaving Trail of Destruction, (Yale Environment360, December 17, 2015),

<http://e360.yale.edu/features/indonesian_coal_mining_boom_is_leaving_trail_of_destruction>.

21 Interview with Naem (Kutai Kertanegara, 26 May 2017).

22 Interview with Pradarma Rupang (Lung Anai Village, 28 May 2017).

23 M.S Buana, Hak Masyarakat Adat atas Sumber Daya Alam: Antara Doktrin Pembangunan dan Hak Asasi Manusia (Indigenous Peoples' Rights on Natural Resources: Between Developmentalism and Human Rights), presented at the $3^{\text {rd }}$ National Conference on Human Rights and Ecological Justice, Tadulako University, Palu 1 -2 March 2017.

24 W Mendelson, Law and Development of Nations, The Journal of Politic, Vol 32, The University of Texas Austin, (1972), 121.

25 H Spencer, The Men versus the State: With Six Essays on Government, Society and Freedom, Liberty Classic, 1884, 127. 
economic surplus. It is time to pay its debt to society through populist policies, including incentives, grants and subsidises for disadvantaged groups and people. ${ }^{26}$

Mendelson analyses why many developing countries fail to cope with development and modernisation. Developing countries, he argues, mix the three stages of development concurrently; as a result, the state's policies contradict each other and cannot be effectively implemented. This policy of concurrence fails to spur effective development, as legal guarantees for corporations and investors take priority over workers' rights or sustainable development. An emphasis on human rights will lessen the progress of industrialisation, making it costly and burdensome. ${ }^{27}$

The historical record supports Mendelson's arguments. In the past, today's developed countries did not undergo the three stages of development concurrently. Britain, for instance, underwent the unification process when King Henry II united England, Wales, Ireland, and Scotland under the British Empire, and the king forced his colonies to uphold the court's jurisdiction. When Britain commenced its Industrial Revolution in the late $18^{\text {th }}$ century, all feudalist acts were revised to encourage investment and trade. ${ }^{28}$ With the example of Britain, Mendelson demonstrates that state law must follow economic development and industrialization.

Japan underwent a similar process during its slow departure from isolation. The historically feudal political structure of Japan was centralized under the Tokugawa Shogunate, which unified the judicial system and demanded subordination. ${ }^{29}$ During Japan's Industrial Revolution, the Meiji Administration encouraged an industrialist political paradigm, with economic elites (zaibatsu) controlling the government. The strategy was effective; by 1939, Japan's GNP had reached a new high. ${ }^{30}$ Despite its defeat in World War II, Japan has cultivated long-lasting economic prosperity, which helped it to reconstruct its post-war economy and become a welfare state in Asia. ${ }^{31}$

Mendelson states that Britain and Japan survived their processes of development because they did not mix the three stages, but executed them consecutively. This policy of consecutive development has been proven effective and comprehensive. ${ }^{32}$

Hager argues that concurrent development is further complicated by the unwillingness of lawyers and economists in developing countries to collaborate in generating effective public policy. State law should actively promote economic growth, not become a hurdle to it. $^{33}$ Economic-driven law is trusted to have a 'persuasive force' to adapt the state to globalisation. $^{34}$ Additionally, to effectively combine economic motives and state law,

\footnotetext{
26 Mendelson, supra note 24, 121.

27 Ibid 114.

28 Ibid.

29 E.O Relschauer, History of Japan, $3^{\text {rd }}$ edition, Knopf, New York, page: 123

30 K Ohkawa and Henry Rosovky, A Century of Japanese Economic Growth, in a State and Economic Enterprise in Japan (Princeton University Press, 1985), 109

31 Mendelson, supra note 24, 345.

32 Ibid.

33 M Hager, The Role of Lawyers in Developing Countries, Journal: Law and the Developing Countries, Texas Austin, 256.

34 H Grossmann, Hukum Akumulasi dan Keruntuhan Sistem Kapitalisme, (Jakarta: Hasta Mitra-YSIK, 2001$), 65$
} 
legislation should support economic growth, and the executive branch should be encouraged to deliver discretion that supports investment in various sectors of industry. ${ }^{35}$

Developmentalism can be summarised by three core aspects: First, the three phases of development should be executed consecutively, rather than concurrently. Second, global market interests should subordinate state law, thereby ensuring that laws concering business are designed to stimulate investment and expansion. Third, laws should aim to create stability and legal certainty to support a friendly environment for investment. ${ }^{36}$ Based on the strong link between state actors and economic actors illustrated by developmentalism, it is clear that the develomentalist paradigm could trigger the establishment of a statecorporatism regime, the notion of which is strongly rejected by human rights activists.

\section{Rights Approach to Development}

The fundamental arguments of human rights are equality and freedom. Both are interlinked with each other. Humans are inherently equal and they have fundamental freedoms that can also be limited by others' rights. Developmentalism disregards human rights because it merely considers humans as object of development by negating their freedoms and rights. Thus the examples of England and Japan cannot be easily generalised, because every human has universal rights that are based upon the principles of equity, sameness of opportunities, and access to justice for marginalised groups. ${ }^{37}$

The essence of human rights is described in the United Nations Charter, as follows:

The purpose of the UN included the development of friendly relations based on the principle of equal rights and self-determination ${ }^{38} \ldots$ and the promotion and encouragement of respect to human rights and fundamental freedom for all without distinction as to race, sex, language or religions. ${ }^{39}$

Furthermore, the Universal Declaration of Human Rights (UDHR) states a similar idea:

By virtue of which every human person and all peoples are entitled to participate in, contribute to, and enjoy economic, social, cultural and political development, in which all human rights and fundamental freedom can be fully realized. ${ }^{40}$

Despite the fact that neither the UN Charter nor UDHR are legally binding documents, they can still be used as moral force for members of the UN. The two main covenants of human rights, the International Covenant on Civil and Political Rights (ICGPR) and the International Covenant on Economic, Social and Cultural Rights (ICESC), have also stated more concrete laws on human rights. Both covenants enrich rather than contradict each other. ${ }^{41}$

35 K Pistor and Philip A. Wellons, The Role of Law and Legal Institution in Asian Economic Development 1960-1995, Oxford University Press, 1998, pages :19

36 Buana, supra note 2, 11.

37 Ibid.

38 The United Nations Charter, Article 1 (2).

39 The United Nations Charter, Article 1 (3).

40 Universal Declaration of Human Rights, Article 1.

41 O Umozurike, Human Rights and Development, UNESCO (1998), 536. 
The interlinkage of the two covenants was stressed by the Declaration on the Right to Development (DRD). The DRD obliges countries to create an inclusive development by implementing ICCPR (Articles 1-21) and ICESG (Articles 22-28) equally. ${ }^{42}$ The key persons of this declaration were the former President of the United States of America (USA) Franklin Roosevelt and his wife Eleanor Roosevelt. They said: "(w)e are writing a bill of rights for the world, and ... one of the most important rights is the opportunity for development." "43

In 1993, the Second UN World Conference on Human Rights stipulated the second DRD, which was accepted by almost all member states including the USA. The 1993 Declaration stipulated some normative rights; specifically, that humans should be central subjects to development, in order to actively contribute and to enjoy their fundamental rights of development. ${ }^{44}$ To encourage inclusive development, the 1993 Declaration also pushed UN members to take more active roles in spreading the wealth to marginalised people and people living near development projects. ${ }^{45}$ Ultimately, it is clear that developmentalism contradicts principles of human rights, because both concepts have different purposes. Developmentalism aims merely on the quantitative aspect of development, while human rights aim to reach a standard quality of development. ${ }^{46}$

In sum, the core arguments of the 1993 Declaration are as follows: First, the right to sustainable development is a human right. In other words, the principles of human rights must inform any process of development. Second, development should be delivered inclusively by considering civil, political, economic, and socio-cultural rights. This is in line with the principles of indivisibility and interdependence. Third, the detriments of development should be negated by providing expanded freedoms to those affected. People should have access to development, to obtain transparency, accountability, and a fair distribution of corporate income. Fourth, the country has obligations to fulfill the rights to development.

It important to bear in mind that above argument is normative. The Indonesia government has ratified the two main human rights covenants, and amended the 1945 Constitution to include human rights legislation. It has also stipulated several legal acts regarding human rights. However, the violation of indigenous and marginalised peoples' human rights is still ongoing. Clearly, reforming legislation alone is insufficient. Civil society organisations must continually advocate for greater human rights protections, because 'laws in action' are often worse than 'laws in book'.

The next section examines empirical conditions in two areas in East Kalimantan rich in natural resources. The decision to conduct fieldwork in this region was motivated by the theory that the remaining form of indigenous advocacy, indigenous spirituality, is deterioting due to the hegemony of the government and extractive companies.

42 The Declaration on the Right to Development, 1986.

43 G Johnson, The Contribution of Eleanor and Franklin Roosevelt to the Development of International Protection for Human Rights, Human Rights Quarterly 9, 1, 19-48.

44 The Declaration on the Right to Development, 1986, Article 3 (2).

45 Ibid, Article 8.

46 A Sengupta, Right to Development as a Human Right, Economic and Political Weekly, Juli 7, $2001,2528$. 


\section{Bontang Municipality and Kutai Kertanegara: Rich yet Fragile Areas}

Bontang City is known for its crude oil and coal production. Its natural resources are critical, not only for local government, but the national government as well. ${ }^{47}$ Due to massive industrial devolepment, almost all areas of the city are fully developed and up-todate. One of the remaining traditional villages of the local indigenous peoples, the Kutai, is Bontang Lestari village. Its original name was Nyerakat, which was taken from the name of the ancient wood used by indigenous peoples as traditional medicine. ${ }^{48}$ This article uses its original name to respect its originality.

Industrialization is highly prevalent in Bontang Lestari village. One way to enter the village is via a paved road constructed by the local coal mining company. The company's security station checks all vehicles prior to entering the village. The village is traditional, but almost all young inhabitants work with the company. Few youngsters are keen to be rice paddy farmers. Villagers' local genius: shifting cultivation has long been abolished.

Despite the rapid rise of industrialization within the village, Nyerakat still has its balian (shaman or witch doctor), a married couple: Mama (mother) Kumala and Abah (father) Masdar. Both are balian who often conduct traditional thanksgiving ceremonies by calling the ancestor spirits and providing alternative traditional health treatment for villagers. As the local spiritual and medical authorities, Mama Kumala and Abah Masdar are charismatic informal local leaders.

Indigenous spirituality is very powerful in Nyerakat village, even though it faces challenges from many external forces. Corporations and the local government have awared with their roles in the village. They have often asked Mama Kumala to assist them in pursuing the local people to sell their land to the companies. Mama Kumala rejected their requests, stating that villagers need their land to survive. ${ }^{49}$ However, the companies claimed the land by negotiating with some pragmatic villagers. Mama Kumala and Abah Masdar are the remaining defenders of indigenous spirituality and autonomy.

Mama Kumala explained the role of indigenous spirituality within the village. Humans should always express their thankfulness toward nature, in order to maintain the cosmic equilibrium. Thus the thanksgiving ceremony is critical to stability within the village. The villagers' ancestors guard nature; female ancestors live on the mainland, while male ancestors live in the air and sea. ${ }^{50}$ This spirituality is neither understood nor prioritizied by the companies or the local government.

In addition to encroachment from capitalist forces, fundamentalist Islamic movements have also challenged Nyerakat's indigenous spirituality. Both Mama Kumala and Abah Masdar are Muslim; however, they embrace their indigenous traditions as well. In 2007, the Council of Ulama (Majelis Ulama Indonesia/MUI) banned Nyerakat's balian-Islamic (syncretist) practice, labeling it as deviant (ajaran sesat). Despite much criticism, Mama Kumala continues her spiritual activities by combining them with her recitation of the Quran. "Adat (custom) and religion are two separated things," said Mama Kumala,

\footnotetext{
47 Interview with Naem (Kutai Kertanegara, 26 May 2017). There are many 'big names' whom are national legislators, bureaucrats and high rank of army officers involving in this regional businesses.

48 Interview with Abah Masdar, (Nyerakat village, 23 May 2017).

49 Interview with Mama Kumala (Nyerakat village, 23 May 2017).

50 Interview with Abah Masdar (Nyerakat village, 23 May 2017).
} 
"however, they are not contradictory ... without adat, we will be extinct ... because that is the way to respect nature and sustain the equilibrium." 51 This indigenous spirituality, if managed well, can be an effective medium to demand advocacy and autonomy for indigenous peoples.

Nyerakat village has different context with another indigenous village: Guntung village. However, both have shared similarly bitter experiences. National and multinational companies have seized control over both these indigenous villages. Liquid Natural Gas (LNG) Badak and Pupuk Kaltim, large multinational corporations, came to the village in 1974. The companies have exploited Bontang's coastal areas, removing the mangrove forests that help protect the village from erosion. ${ }^{52}$ Bontang City in general has come to be dominated by these destructive companies both in its coastal neighborhoods and in the more mountainous areas.

Villagers of Guntung now face several dilemmas, as companies have affected their living environment significantly. Water and air pollution are highly prevalent, due to ammoniac waste. On the other hand, most young people in the village work for the companies; consequently, villagers are financially dependent on their presence. The influence of the companies has weakened indigenous spirituality within the village, even though their balai (a place to gather traditional and religious ceremonies) was established by the company's CSR (Corporate Social Responsibility) program. In Guntung village, statecorporatism has prevailed over indigenous spirituality.

The indigenous villages of Lung Anai and Kuntab in Kutai Kertanegara Regency offer a further look into the effects of development in the area. The journey to Lung Anai takes around 2-3 hours from the capital city of East Kalimantan, Samarinda. The village of Lung Anai is highly distinctive from its neighbouring Muslim-Malay villages. Indigenous nonMuslim villages can be easily identified, in part, by the presence of wild dogs within the roads leading to them. Due to its distinctive culture, Lung Anai has been recognised by the Kutai Kartanegara government as a cultural village since 2007. The village is around 160 hectares, and is inhabited by about 370 families. ${ }^{53}$ Although the local government legally recognizes the village, autonomy and prosperity remain fragile, due to the following reasons:

First, there is a weak bond between the villagers and their lands. According to one of the elders, indigenous peoples never exercise slash-and-burn cultivation methods in Lung Anai, because the lands do not belong to them. Lung Anai village is not their original birthplace; they moved from Apokayan (near Sarawak, Malaysia) in $1984 .^{54}$ As such, they do not have a strong connection to the lands they they have occupied only recently. It is worth noting that within the definition of indigenous peoples (adatrechtsgemeenshappen) in Dutch and Indonesian national law, one of the prerequisites of national recognition is a strong spiritual (religio-magis) relationship between indigenous peoples and their communal

51 Interview with Mama Kumala (Nyerakat village, 23 May 2017).

52 Interview with Ismail (Guntung village, 25 May 2017).

53 Interview with Amay Ubak (Lung Anai village, 27 May 2017).

54 Interview with Amay Ubak (Lung Anai village, 27 May 2017). 
lands. ${ }^{55}$ This requirement defines indigenous peoples as strictly land-based communities. Based on that definition, the villagers of Lung Anai are disregarded as 'indigenous peoples'.

The exclusion of the Lung Anai villagers from 'indigenous peoples' status has opened up the village to external exploitation. 15 corporations have begun operations there. Nine of them are open-pit coal-mining companies, while the rest are palm oil plantations, timber, and bottled water companies. ${ }^{56}$

Second, erau, a traditional thanksgiving ceremony, is often celebrated within the village; however, this indigenous rite has been transformed into a mere tourist attraction. Adat and local wisdoms have been abolished due to the presence of fundamentalist Christianity in the region. The role of balian has long been abolished, replaced by Christian priests and modern doctors. Indigenous women were once known for their practice of growing very long earlobes, but this practice has ended. ${ }^{57}$ The villagers abolished their indigenous traditions and spirituality because those traditions and spirituality hamper their economic activities, and are not stated or obligated in Bible. Therefore, the villagers have no obligation to conserve forests and other resources, because there is no longer a spiritual bond between them and nature.

According to one of the elders, indigenous spirituality was originally abolished due to anti-communist sentiment in 1960s. Prior to their resettlement in Lung Anai, indigenous peoples lived in Apokayan, where they were given only two choices: accept Christianity (Protestantism or Catholicism), or be labeled as communists. As such, the indigenous peoples were forced to forego their rituals. ${ }^{58}$ This forced conversion was a fundamental violation of their human rights. Their resettlement to Lung Anai was also sponsored by the government as a 'stepping stone' strategy to lessen their spirituality and then exploit their natural resources. ${ }^{59}$ Lung Anai's experiences demonstrate that imported religions and development projects can work hand in hand to exploit and discriminate against indigenous peoples.

This article concludes that Lung Anai village is merely a tourism village. Their dancing performances and erau have lost their spiritual values. The status of 'cultural village' that has been given by the local government was only a mask to cover massive exploitations and natural destruction within the village. These phenomena can be called a neo-orientalism or self-exoticism. ${ }^{60}$

The village of Kuntab has a different cultural and historical context from Lung Anai. Unlike Lung Anai, which is a cultural village, Kuntab village is only a small sub-village

55 Buana, supra note 2, 22.

56 Interview with Amay Pelujuk (Lung Anai village, 27 May 2017).

57 Interview with Amay Pelujuk (Lung Anai village, 27 May 2017).

58 Interview with Amay Ubak (Lung Anai village, 27 May 2017).

59 A Azis, Agama, Pembangunanisme dan Perusakan Ruang Hidup Mahakam (Religion, Developmentalism and Desctruction of Living Space in Mahakam), Paper presented at Seminar Pemburukan Kerusakan Kalimantan: Pertukaran Catatan dan Pengalaman dari Garis Depan Krisis, (Sajogyo Institute, Centre for Women and Childs, Faculty of Law Mulawarman University, Nahdlatul Ulama University East Kalimantan, and School of Democratic Economics, Samarinda, 9 May 2017).

60 M Pichard, "Cultural Tourism" in Bali: Cultural Performances as Tourist Atraction, Indonesia, 49 (April, 1990) 37-74. See generally, M Pichard and Robert E. Wood, Tourism, Ethnicity and the State in Asian and Pacific Societies (Honolulu: Hawai'i University Presss, 1997). 
(dusun). However, indigenous spiritualties are more manifest in this village. Mama (mother) Supinah is the only balian in this village. She is known for her spiritual ability to forecast weathers and to remedy 'black magic' practices. Balian have some practical roles, such as predicting the best time to plant rice or to expand rice paddies, and determining which trees cannot be cut down and which catchment areas must be preserved. Failing to accomplish these duties leads to devastation. As harvest time approaches, it is compulsory for villagers to conduct a thanksgiving ceremony to maintain equillibrum between the human, natural, and spiritual words. ${ }^{61}$

Unlike in Lung Anai, in Kuntab village, slash-and-burn cultivation is still practiced by the villagers. ${ }^{62}$ They have a strong connection with their communal lands. This cultural characteristic demonstrates proof that Kuntab's villagers are 'legally-based indigenous peoples.' Because of the diligence of Kuntab's balian, the village is known for the cleanest water supply in all of Kutai Kertanegara Regency. It still has dense forests with plenty of traditional plants.

With regards to indigenous spirituality, Mama Supinah said that she was born as an Ahmadiyyah Muslim, but then converted to her local religion because Ahmadiyyah Muslim communities could not accept her 'ability' and demanded reununciation. Ahmadiyyah, a trans-national Muslim sect, is extremely doctrinal. Mama Supinah said labelled this form of Islam as 'New Islam' (Islam Baru), which cannot be integrated with local cultures and traditions. She prefers to associate with practitioners of 'Old Islam' (Islam Lama), which is promoted by the organization Nahdathul Ulama (NU). She considers them to be more tolerant toward local traditions. ${ }^{63}$ Mama Supinah said that there is no real contradiction between religion and traditional beliefs, because indigenous spiritualitual practices do not worship tress and nature, but instead create and maintain cosmological equilibrium. ${ }^{64}$ This model of religious syncretism is an opportunity for the government to encourage a more friendly and tolerant Islamic movement, so as to encourage cooperation between Muslisms and indigenous believers. Spirituality can then be used as a social capital to lessen injustice and discrimination.

Despite the current condition of Kuntab village is relatively preserved compared to Lung Anai village, there are some future challenges awaits. Companies are persuasively seized the villages. There are two palm oil plantations nearby the village and a logging company that ready to take over indigenous lands in near future. ${ }^{65}$ This is wake up call for indigenous peoples and activists to defend their lands and local traditions.

\section{CONCLUSION}

This investigation can be utilized as a reflection on future strategies of indigenous peoples' advocacy. In order to better Indonesian human rights, the government has undergone several legal reform strategies, from stipulating responsive legislation to reforming the

\footnotetext{
61 Interview with Mama Supinah, (Kuntab village, 28 May 2017).

62 Interview with Mama Supinah, (Kuntab village, 28 May 2017).

63 Interview with Mama Supinah, (Kuntab village, 28 May 2017).

64 Interview with Mama Supinah, (Kuntab village, 28 May 2017).

65 Interview with Kahar Al- Bahri, (Samarinda, 20 May 2017).
} 
judicial system. However, neither has proven effective. The reason why almost all legalformal mechanisms are ineffective is because the mechanisms of the state (through judicial and legal drafting processes) have been occupied by state-corporatism, both in the national and regional arenas. Thus, defenders of indigenous rights should find another strategy into which state-corporatism cannot penetrate. In this case it is reasonable to consider the Advocacy Theory, namely 'The Prophet and King' strategy. The Prophet is a spiritual leader, the one who appoints 'the King' as a formal leader. In this theory, we can lose 'the King', but we must keep 'the Prophet' alive no matter what. This article argues that indigenous spirituality is a key to battle state-corporatism's influences, despite the fact that in some areas, state-corporatism has co-opted indigenous spirituality through its 'financial aids.' However, indigenous spirituality as forum internum, a private conscience of human being, is still a potential tool of advocacy, because it is a private and personal belief. By capitalizing on the role of shamans, indigenous peoples might still have an opportunity to reclaim and defend their communal and cultural rights.

\section{BIBLIOGRAPHY}

\section{BOOKS AND JOURNALS}

Buana, M.S, Understanding Indigenous Cultural Rights in Indonesia through the logic of Village Law: A Nexus between Governance Networks and Legal Pluralism (Forthcoming in September 2017).

Crook, R and James Manor, Democracy and Decentralization in South Asia and West Asia (Cambridge: Cambridge University Press, 1998).

Funchs, Doris, Lederer and Markus ML, et al, "The Power of Business" (2007) 9(3) Business and Politics.

Grossmann, H, Hukum Akumulasi dan Keruntuhan Sistem Kapitalisme, (Jakarta: Hasta MitraYSIK, 2001).

Hager, M, The Role of Lawyers in Developing Countries, Journal: Law and the Developing Countries, Texas Austin.

Johnson, G, The Contribution of Eleanor and Franklin Roosevelt to the Development of International Protection for Human Rights, Human Rights Quarterly 9.

Mendelson, W, Law and Development of Nations, The Journal of Politic, Vol 32, The University of Texas Austin, (1972).

Ohkawa, K and Henry Rosovky, A Century of Fapanese Economic Growth, in a State and Economic Enterprise in Japan (Princeton University Press, 1985).

Pichard, M and Robert E. Wood, Tourism, Ethnicity and the State in Asian and Pacific Societies (Honolulu: Hawai'i University Presss, 1997).

Pichard, M, "Cultural Tourism" in Bali: Cultural Performances as Tourist Atraction, Indonesia, 49 (April, 1990).

Pistor, K and Philip A. Wellons, The Role of Law and Legal Institution in Asian Economic Development 1960-1995, Oxford University Press, 1998.

Relschauer, E.O, History of Japan, $3^{\text {rd }}$ edition, Knopf, New York. 
Ribot, J, Waiting for Democracy: The Politics of Choice in Natural Resource Decentralization (World Resource Institute, 2004).

Sengupta, A, Right to Development as a Human Right, Economic and Political Weekly, Juli 7, 2001.

Spencer, H, The Men versus the State: With Six Essays on Government, Society and Freedom, Liberty Classic, 1884.

Umozurike, O, Human Rights and Development, UNESCO (1998).

Vidyattama, Y, Hares and Tortoises: Indonesia's Regional Development Kaleidoscope (Presentation to the ANU Indonesia Update, September 20, 2013).

Weiss, L, The Limit of Powerless State, (Cornell: Cornell University Press, 1998).

Wolman, H, Decentralization: what it is and why we should care in Bennett RJ (ed), Decentralization, Local Government, and Market: Toward A Post-War Welfare Agenda (Oxford: Clarendon, 1990).

\section{CONFERENGE PAPERS}

Azis, A, Agama, Pembangunanisme dan Perusakan Ruang Hidup Mahakam (Religion, Developmentalism and Desctruction of Living Space in Mahakam), Paper presented at Seminar Pemburukan Kerusakan Kalimantan: Pertukaran Catatan dan Pengalaman dari Garis Depan Krisis, (Sajogyo Institute, Centre for Women and Childs, Faculty of Law Mulawarman University, Nahdlatul Ulama University East Kalimantan, and School of Democratic Economics, Samarinda, 9 May 2017).

Buana, M.S, Hak Masyarakat Adat atas Sumber Daya Alam: Antara Doktrin Pembangunan dan Hak Asasi Manusia (Indigenous Peoples' Rights on Natural Resources: Between Developmentalism and Human Rights), presented at the $3^{\text {rd }}$ National Conference on Human Rights and Ecological Justice, Tadulako University, Palu 1 -2 March 2017.

\section{DISSERTATION}

Buana, M.S, State Courts, Traditional Dispute Resolution and Indigenous Peoples in South Kalimantan: A Socio-Legal Study (PhD Thesis, University of Queensland, 2017).

Faisal, M, State Structural and Institutional Transformation and the New Dynamics of Business Power, Corruption and Clientelism in Indonesia, (PhD Thesis, University of Queensland, 2013).

\section{INTERVIEWS}

Interview with Pradarma Rupang (Lung Anai Village, 28 May 2017). Interview with Kahar Al- Bahri, (Samarinda, 20 May 2017). Interview with Abah Masdar, (Nyerakat village, 23 May 2017). Interview with Ketut (Nyerakat village, 22 May 2017). 
Interview with Naem (Kutai Kertanegara, 26 May 2017).

Interview with Abah Masdar, (Nyerakat village, 23 May 2017).

Interview with Mama Kumala (Nyerakat village, 23 May 2017).

Interview with Ismail (Guntung village, 25 May 2017).

Interview with Amay Ubak (Lung Anai village, 27 May 2017).

Interview with Amay Pelujuk (Lung Anai village, 27 May 2017).

Interview with Mama Supinah, (Kuntab village, 28 May 2017).

\section{INTERNATIONAL TREATIES}

The United Nations Charter

Universal Declaration of Human Rights

The Declaration on the Right to Development

\section{WEBSITES}

Indonesia's Coal Mining Sector: A Silver Lining behind Dark Clouds, Global Business Guide Indonesia <http://www.gbgindonesia.com/en/energy/article/2016/indonesia_s_coal_mining_secto r_a_silver_lining_behind_dark_clouds_11613.php>

<http://www.mongabay.co.id/2017/03/27/masyarakat-kalimantan-timur-menderitaakibat-lingkungan-yangrusak/\#>.

$<$ http://www.kliktenggarong.com/berita-2079-1404-izin-tambang-tumbuh-dikukar.html>.

Ives, M, Indonesia Coal Mining Boom is Leaving Trail of Destruction, (Yale Environment360, December 17, 2015) <http://e360.yale.edu/features/indonesian_coal_mining_boom_is_leaving_trail_of_destru ction>. 